\title{
Shortcut nitrification/partial nitritation start-up for reject water treatment in a SBR
}

\author{
Mateusz Muszyński-Huhajło ${ }^{1, *}$, and Stanisław Miodoński ${ }^{1}$ \\ ${ }^{1}$ Faculty of Environmental Engineering, Wroclaw University of Science and Technology, Wybrzeże \\ Wyspiańskiego 27, 50-370 Wroclaw, Poland
}

\begin{abstract}
For many wastewater treatment plants (WWTPs), side-stream treatment of reject water from digested sludge dewatering is a feasible opportunity to improve N-removal efficiency without costly plant expansion. Biological nitrogen removal over nitrite or combined partial nitritation (PN)-Anammox process has recently become a popular treatment method for such ammonium-rich streams. Shortcut nitrification and PN start-ups were successfully performed in a pilot-scale SBR treating real reject water. In all performed experiments, effective nitrate production inhibition occurred in less than 20 days due to operational conditions selection and without advanced control system. $\mathrm{pH}$ adjustment in the PN reactor allowed to achieve $\mathrm{NO}_{2}-\mathrm{N} / \mathrm{NH}_{4}-\mathrm{N}$ ratio suitable for Anammox process $(1.24 \pm 0.07)$.
\end{abstract}

\section{Introduction}

High quality standards for wastewater treatment plant (WWTP) effluent induce constant development of new technologies, especially considering biological nutrient removal (BNR). In the last decade, researcher's attention attracted alternative technologies for nitrogen removal, especially connected with treating high-strength ammonium streams (i.e. reject water from sludge dewatering), named as side-stream treatment [1]. Specific characteristics of this medium, such as high ammonium concentration and temperature, create a convenient opportunity to avoid further nitrite oxidation in the second stage of nitrification by selective NOB (Nitrite Oxidizing Bacteria) inhibition. Such approach can be described as shortcut nitrification if the main goal is to oxidize whole ammonium load into nitrite. Main advantages of this process are: reduction of specific cost of $1 \mathrm{~g} \mathrm{NH}_{4}-\mathrm{N}$ oxidation due to lower oxygen consumption, less organic carbon required in further denitrification if such occurs later (i.e. SHARON process) [2], production of nitrite-rich medium that can be a useful source of free nitrous acid (FNA) [3] and activated sludge production enriched with AOB (Ammonia Oxidizing Bacteria) for mainstream bioaugmentation purposes [4]. Despite only slight difference in the amount of ammonium load oxidized, it seems to be important to distinguish a specific type of shortcut nitrification - partial nitritation (PN) used as a necessary pre-treatment preceding Anammox process. In this case the main goal is to oxidize part of the ammonium load, achieving $\mathrm{NO}_{2}-\mathrm{N} / \mathrm{NH}_{4}-\mathrm{N}$ ratio in the effluent around 1.32, reported as stoichiometric in Anammox reaction [5].

${ }^{*}$ Corresponding author: mateusz.muszynski-huhajlo@pwr.edu.p1 
Rising popularity of this process can be proven by over $100 \mathrm{PN} /$ Anammox installations operating worldwide by 2014 [6].

Paper contains detailed description of selected factors affecting NOB activity in wastewater treatment systems that may be used to achieve severe inhibition of this nitrifiers group. Based on gathered theoretical information, a simple start-up strategy for shortcut nitrification/PN was developed and successfully tested in a pilot-scale SBR treating real reject water from sludge dewatering at one of Polish WWTPs.

\subsection{Nitrification and factors affecting NOB activity.}

Nitrification is one of the fundamental biological processes in wastewater treatment and key element of nitrogen removal processes. This two-stage biochemical, autotrophic process of ammonia $\left(\mathrm{NH}_{3}\right)$ oxidation to nitrate $\left(\mathrm{NO}_{2}{ }^{-}\right)$by $\mathrm{AOB}$ and further nitrite oxidation to nitrate $\left(\mathrm{NO}_{3}^{-}\right)$by $\mathrm{NOB}$. According to reaction stoichiometry, complete oxidation of $1 \mathrm{~g}$ of $\mathrm{NH}_{3}-\mathrm{N}$ to nitrate requires $4.57 \mathrm{~g}$ of oxygen, where $3.43 \mathrm{~g} \mathrm{O}_{2}$ is used for nitritation, which also consumes alkalinity due to hydrogen ions production $\left(7.14 \mathrm{~g} \mathrm{CaCO}_{3}\right.$ per gram $\mathrm{NH}_{3}-\mathrm{N}$ oxidized) [7].

In conventional activated sludge systems, where complete nitrification is key element in the nitrogen removal process, process conditions are usually adjusted to meet the requirements for stable growth and activity of both groups of nitrifiers, however, in some advanced treatment technologies only nitritation is considered as enough for N-removal. $\mathrm{AOB}$ and NOB, which has no phylogenetic relation between themselves, reveal slight differences in environmental conditions tolerance range and growth kinetics which might be used to induce selective inhibition of NOB. Selected factors that can be used to promote only AOB activity are discussed in this point.

\subsubsection{Temperature}

Temperature has significant impact on nitrification process. A common phenomenon is periodical nitrite build-up observed, both in natural waters [8] and activated sludge systems [9] during elevated temperature period in summer. This fact can be explained by different activity characteristics of two nitrifiers groups: AOB show greater activity than NOB at higher temperatures $\left(>14^{\circ} \mathrm{C}\right)[10]$. Nitrifiers net growth rate at $25^{\circ} \mathrm{C}$ equals 0.86 and $0.77 \mathrm{~d}^{-1}$ for $\mathrm{AOB}$ and $\mathrm{NOB}$, respectively. As the temperature rises, this difference increases to about $28 \%$ at $30^{\circ} \mathrm{C}$ and $38 \%$ at $35^{\circ} \mathrm{C}$ in favour of the AOB [11]. As reject water from sludge dewatering usually have relatively high temperature, this feature is commonly used as one of main nitrifiers selection mechanism in side-stream treatment technologies.

\subsubsection{Sludge Retention Time (SRT)}

In optimal conditions, AOB grow faster than NOB as minimal doubling time for each group, $7-8 \mathrm{~h}$ for ammonia oxidizers and $12-13 \mathrm{~h}$ for nitrite oxidizers [12]. SRT, as one of fundamental operational parameters characterising activated sludge systems, can be a useful tool to reduce NOB presence in biomass structure. Setting SRT higher than minimal SRT required for keeping $\mathrm{AOB}$ in the reactor and lower than minimal required for NOB will wash-out them from the system. Minimal SRT for each nitrifiers groups depends on various parameters so it is very important to maintain properly balanced operating conditions which promote only AOB. 


\subsubsection{Dissolved oxygen (DO) concentration}

Availability of oxygen, the final electron acceptor in nitrification process, is one of its limiting factors. In general, DO concentration around $2 \mathrm{~g} \mathrm{O}_{2} / \mathrm{m}^{3}$ is traditionally considered as optimal for complete nitrification, both for technological and economic reasons. By eliminating nitrite oxidation from the whole process, oxygen consumption can be reduced by $25 \%$. Like in case of growth kinetics, two groups of nitrifiers also has different affinity constants for oxygen. It was shown that AOB has higher oxygen affinity. Oxygen saturation constant are 0.3 and $1.1 \mathrm{~g} \mathrm{O}_{2} / \mathrm{m}^{3}$ for $\mathrm{AOB}$ and $\mathrm{NOB}$ respectively [13] however, range of values found in the literature for this parameter is quite wide. Possible cause of such discrepancies is the difference between oxygen concentration in the liquid phase and the interior of the flocs. These values are therefore dependent on the density of the flock structure, their size and diffusion efficiency [14]. Summarizing, DO concentrations below $1 \mathrm{~g} \mathrm{O}_{2} / \mathrm{m}^{3}$ result in a gradual elimination of NOB from the system [15].

\subsection{3 $\mathrm{pH}$, Free Ammonia (FA) and Free Nitrous Acid (FNA)}

$\mathrm{pH}$ can be crucial parameter in nitrification process control, as hydrogen ions concentration has impact on nitrifiers enzyme activity [16]. It is generally accepted that optimal $\mathrm{pH}$ range for $\mathrm{AOB}$ and $\mathrm{NOB}$ are $8.2-0.3$ and $7.9-0.4$ respectively [17]. In solutions containing ammonium and/or nitrite nitrogen also their ion forms are present as FA and/or FNA, depending on their initial concentrations, $\mathrm{pH}$ value and temperature [18].

Both substances are known to have inhibitory effect on nitrification process and can be used as a selective force for NOB inhibition due to different inhibition threshold values for each nitrifiers group. For AOB, FA and FNA levels resulting in activity loss are above $10 \mathrm{mg} \mathrm{NH}_{3} / \mathrm{dm}^{3}$ and $0.42-1.72 \mathrm{mg} \mathrm{HNO}_{2} / \mathrm{dm}^{3}$. NOB are much more vulnerable as complete inhibition can be observed in concentrations over $1 \mathrm{mg} \mathrm{NH}_{3} / \mathrm{dm}^{3}$ and $0.026-0.22 \mathrm{mg} \mathrm{HNO}_{2} / \mathrm{dm}^{3}$. Exact values may vary depending on source due to possible biomass adaptation [19] but general conclusion maintains the same - AOB are more resistant to these factors.

Proper control of FA and FNA concentration was used a powerful tool to obtain shortcut/PN in many different processes, especially in reject water treatment. Different approaches on shortcut nitrification/PN were presented in literature, are mostly connected with FA [20-22] rather than FNA [16, 23] as the selective factor.

\section{Materials and methods}

\subsection{Experimental set-up}

\subsubsection{Pilot scale SBR and treated medium characteristics}

Described experiments were performed in a $150 \mathrm{dm}^{3}$ SBRs treating real reject water from digested sludge dewatering. Reactor was operated at predefined time cycles, consisting of filling, reaction (mixing and aeration), sedimentation, decantation phases. Reactor was equipped with number of sensors connected to SCADA system providing parental control of following parameters: temperature, $\mathrm{pH}$ (only base solution addition), DO level, filling/decanting volume and mixing intensity. $\mathrm{NH}_{4}-\mathrm{N} / \mathrm{NO}_{3}-\mathrm{N}$ ion-selective electrode probe was installed in the reactor without connection to SCADA and was used only to control $\mathrm{N}$-compounds concentrations by the operator. 


\subsubsection{Treated medium characteristics}

Pilot installation treated real reject water from a belt press without flushing water (used for belt cleaning) to avoid excessive dilution. Activated sludge after mesophilic digestion (HRT $\sim 40 \mathrm{~d}$ ) was the belt press influent and origin of reject water. Due to intermittent operation of dewatering unit, reject water was collected periodically in a storage tank to provide supply of influent medium for SBR. After filling, medium composition was determined. During start-up period, typical influent ammonium concentration, and alkalinity were equal $622.6 \pm 11.7 \mathrm{~g} \mathrm{NH} 4 \mathrm{~N} / \mathrm{m}^{3}, 53.8 \pm 1.8 \mathrm{val} / \mathrm{m}^{3}$ respectively during Start-up 1 and $779.3 \pm 13.8 \mathrm{~g} \mathrm{NH}_{4}-\mathrm{N} / \mathrm{m}^{3}, 68.6 \pm 1.4 \mathrm{val} / \mathrm{m}^{3}$ during Start-up 2 .

\subsubsection{Analytical methods}

Collected samples were filtered with syringe filters, pore size $1.2 \mu \mathrm{m}$ and after that ammonium, nitrite and nitrate nitrogen concentrations were measured using Hach photometric cuvette tests and a DR3900 spectrophotometer. Total suspended solids (TSS) and volatile suspended solids (VSS) concentrations were determined using direct weight method according to Standard Methods guideline. Nitrification rate tests were performed in the pilot-scale reactor in process conditions (test procedure and data analysis guides were adopted from [24]).

\subsection{Experiment procedure}

Experiments were conducted in pilot-scale SBR to test shortcut nitrification/PN start-up strategies in different $\mathrm{pH}$ conditions. Shortcut nitrification start-up was performed with a conventional, fully nitrifying activated sludge (CAS) from the same WWTP and second experiment was conducted as an attempt to achieve PN from a completely nitrifying enriched sludge treating the same reject water.

To ensure cultivation of similar nitrifying bacteria species as present in the mainstream reactor of the plant, during all experiments SBRs were seeded daily with activated sludge from the main reactor. Each seed portion was equal $20 \%$ of TSS mass in the SBR added once a day.

\subsubsection{Start-up 1: From CAS to shortcut nitrification at elevated pH (FA inhibition)}

Start-up strategy was based on combination of several factors affecting NOB activity (average values): low DO $\left(0.68 \pm 0.04 \mathrm{~g} \mathrm{O}_{2} / \mathrm{m}^{3}\right)$, high temperature $\left(25.14 \pm 0.04^{\circ} \mathrm{C}\right)$, short SRT $(2.92 \pm 0.21$ days $)$ and finally, elevated $\mathrm{pH}(7.81 \pm 0.01)$ to maintain high concentration of FA. Process inoculum, CAS from a municipal WWTP, was seeded into pilot-scale reactor and a single nitrification rate test was performed after few hours of sludge adaptation to new conditions. After that, initial nitrogen loading rate (NLR) was calculated based on observed nitrification rate, aeration phase length and medium $\mathrm{NH}_{4}-\mathrm{N}$ concentration. In the next days of experiment, NLR was increased based on effluent composition data (daily) and periodical nitrification rate test (performed at least once a week) until it reached $0.5-0.6 \mathrm{~kg} \mathrm{NH}-\mathrm{N} \cdot\left(\mathrm{m}^{3} \cdot \mathrm{d}\right)^{-1}$ when further increasing was stopped and reactor was operated in stable conditions. 


\subsubsection{Start-up 2: From enriched sludge to PN at low pH (FNA inhibition)}

Goal of this experiment was to selectively inhibit NOB activity in a completely nitrifying sludge treating real reject water. Prior to described start-up, nitrification was maintained for over 3 months with average effluent composition: $0.6 \pm 0.5,0.5 \pm 0.2$ and $636.2 \pm 19.9 \mathrm{mg} \mathrm{N} / \mathrm{dm}^{3}$ of $\mathrm{NH}_{4}-\mathrm{N}, \mathrm{NO}_{2}-\mathrm{N}$ and $\mathrm{NO}_{3}-\mathrm{N}$ respectively. At the beginning of $\mathrm{PN}$ start-up, NLR was $0.64 \mathrm{~kg} \mathrm{NH}-\mathrm{N} \cdot\left(\mathrm{m}^{3} \cdot \mathrm{d}\right)^{-1}$ and specific AUR (Ammonium Uptake Rate) was equal $0.34 \mathrm{~g} \mathrm{NH}_{4}-\mathrm{N} \cdot(\mathrm{g} \mathrm{VSS} \cdot \mathrm{d})^{-1}$. During complete nitrification period, DO, $\mathrm{pH}$, temperature and SRT were $3.29 \pm 0.11 \mathrm{~g} \mathrm{O}_{2} / \mathrm{m}^{3}, 7.02 \pm 0.08,24.98 \pm 0.03{ }^{\circ} \mathrm{C}$ and $6.1 \pm 0.5$ days respectively.

As alkalinity present in reject water is sufficient for oxidation of about half of $\mathrm{NH}_{4}-\mathrm{N}$ load, to restrain ammonium oxidation, solution used or $\mathrm{pH}$ control was changed from $8 \%$ $\mathrm{NaHCO}_{3}$ to $5 \% \mathrm{NaOH}$. Another step on way to achieve PN was change in reactor operating conditions. Influent load was the same as during complete nitrification operation. While reactor was operated in stable conditions after switch to $\mathrm{PN}$, between $45^{\text {th }}$ and $60^{\text {th }}$ day borderline $\mathrm{pH}$ set point adjustment was performed to achieve proper $\mathrm{NO}_{2}-\mathrm{N} / \mathrm{NH}_{4}-\mathrm{N}$ ratio in the effluent, suitable for the Anammox process. During PN period, average DO, $\mathrm{pH}$, temperature and SRT were $0.81 \pm 0.05 \mathrm{~g} \mathrm{O}_{2} / \mathrm{m}^{3}, 7.03 \pm 0.01(6.44 \pm 0.03$ after $\mathrm{pH}$ set point adjustment), $24.99 \pm 0.02^{\circ} \mathrm{C}$ and $3.13 \pm 0.28$ days respectively.

\section{Results}

\subsection{Start-up 1}

Mainstream CAS, used as inoculum, had initial specific AUR: $0.07 \mathrm{~g} \mathrm{NH}_{4}-\mathrm{N} \cdot(\mathrm{g} \mathrm{VSS} \cdot \mathrm{d})^{-1}$ determined in first nitrification rate test after sludge acclimatisation. During Start-up 1, target NLR $\left(0.6 \mathrm{~kg} \mathrm{NH}-\mathrm{N} \cdot\left(\mathrm{m}^{3} \cdot \mathrm{d}\right)^{-1}\right)$ was reached in 25 days and period of stable operation started. Nitrate presence in the effluent occurred only at days 1-10. After $30^{\text {th }}$ day nitrate presence significantly dropped, due to higher $\mathrm{NH}_{4}-\mathrm{N}$ concentration in the influent resulting in higher FA level supressing NOB activity more effectively. After $30^{\text {th }}$ day average effluent composition was $33.3 \pm 10.3,416.6 \pm 20.5$ and $11.1 \pm 4.1 \mathrm{mg} \mathrm{N} / \mathrm{dm}^{3}$ of $\mathrm{NH}_{4}-\mathrm{N}, \mathrm{NO}_{2}-\mathrm{N}$ and $\mathrm{NO}_{3}-\mathrm{N}$ respectively. Average nitrite accumulation rate (NAR) was $97 \pm 1 \%$ while specific AUR was $0.41 \pm 0.04 \mathrm{~g} \mathrm{NH}_{4}-\mathrm{N} \cdot(\mathrm{g} \mathrm{VSS} \cdot \mathrm{d})^{-1}$. Average FA and FNA were $2.91 \pm 0.31 \mathrm{mg} \mathrm{NH} / \mathrm{dm}^{3}$ and $<0.015 \mathrm{mg} \mathrm{HNO}_{2} / \mathrm{dm}^{3}$ respectively. Figure 1 presents effluent composition and NAR during whole experiment.

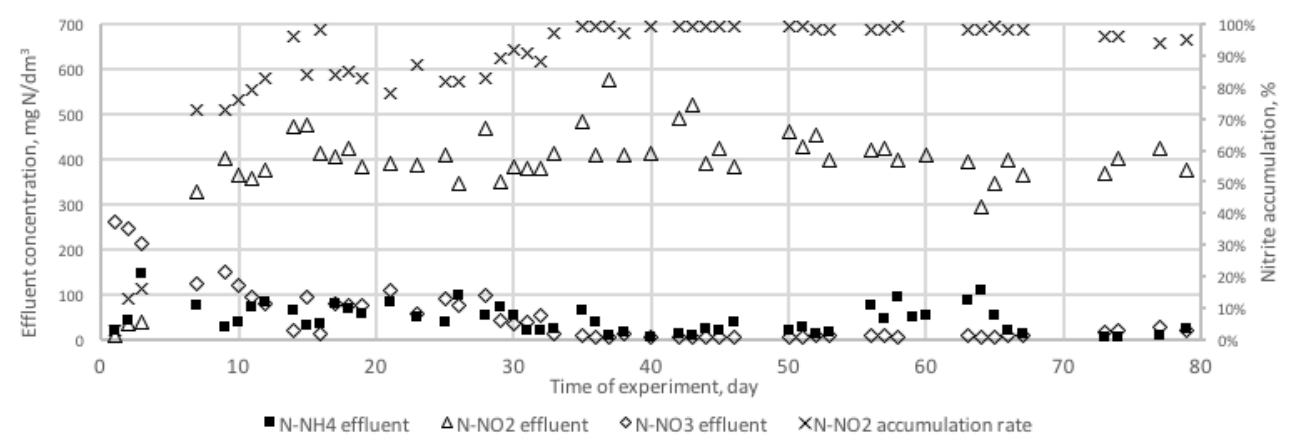

Fig. 1. NAR and effluent composition during Start-up 1. 


\subsection{Start-up 2}

Operating conditions and typical effluent composition during complete nitrification period preceding this start-up were presented in section 2.2.2. At $6^{\text {th }}$ day after start-up experiment begun, solution for $\mathrm{pH}$ control was changed, until this time complete nitrification occurred. Due to alkalinity limitation, $\mathrm{NH}_{4}-\mathrm{N}$ build-up started alongside with nitrite accumulation. Increased $\mathrm{NH}_{4}-\mathrm{N}$ and $\mathrm{NO}_{2}-\mathrm{N}$ concentrations resulted in higher FA and FNA level which induced very effective NOB inhibition as NAR grow up to almost $80 \%$ in a week. Almost complete suppression of NOB activity can be observed since $30^{\text {th }}$ day of experiment as only residual $\mathrm{NO}_{3}-\mathrm{N}$ can be noticed in the effluent. After $30^{\text {th }}$ day, average effluent was $336.6 \pm$ $22.5,466.3 \pm 10.8$ and $6.6 \pm 0.9 \mathrm{mg} \mathrm{N} / \mathrm{dm}^{3}$ of $\mathrm{NH}_{4}-\mathrm{N}, \mathrm{NO}_{2}-\mathrm{N}$ and $\mathrm{NO}_{3}-\mathrm{N}$ respectively. In this period, average specific AUR was $0.39 \pm 0.04 \mathrm{~g} \mathrm{NH}_{4}-\mathrm{N} \cdot(\mathrm{g} \mathrm{VSS} \cdot \mathrm{d})^{-1}$ and NAR was $99 \pm 0.3 \%$. To achieve $\mathrm{NO}_{2}-\mathrm{N} / \mathrm{NH}_{4}-\mathrm{N}$ ratio suitable for Anammox process, borderline $\mathrm{pH}$ was finally set to 6.4 at $60^{\text {th }}$ day. Since then, average nitrite/ammonium ratio was $1.24 \pm 0.07$ which can surely be considered as suitable as Anammox process. Until $45^{\text {th }}$ day average FA and FNA levels were $1.51 \pm 0.21 \mathrm{mg} \mathrm{NH}_{3} / \mathrm{dm}^{3}$ and $0.09 \pm 0.01 \mathrm{mg} \mathrm{HNO} / \mathrm{dm}^{3}$ respectively. In period after $\mathrm{pH}$ adjustment, average concentrations of these substances were $0.64 \pm 0.03 \mathrm{mg} \mathrm{NH}_{3} / \mathrm{dm}^{3}$ and $0.38 \pm 0.01 \mathrm{mg} \mathrm{HNO} 2 / \mathrm{dm}^{3}$.

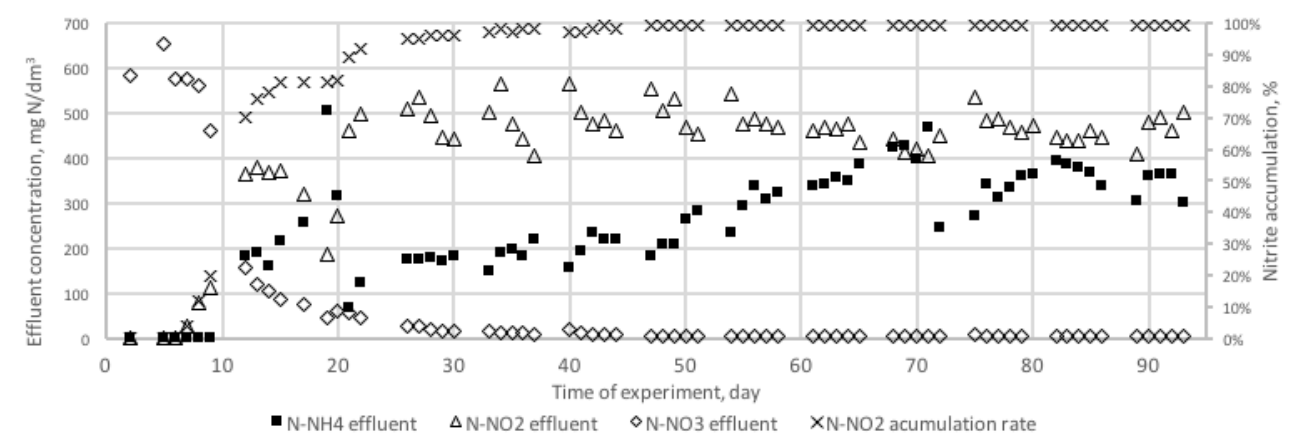

Fig. 2. NAR and effluent composition during Start-up 2.

\section{Conclusions}

-Shortcut nitrification/PN start-up strategy based on simple control of operational conditions in the reactor has proven to be successful and allows to obtain stable NOB activity suppression within two weeks.

- Combination of low DO level $\left(0.7 \mathrm{gO}_{2} / \mathrm{m}^{3}\right)$, high temperature $\left(25^{\circ} \mathrm{C}\right)$, short SRT (3 days) and FA inhibition in start-up based on conventional activated sludge was sufficient to achieve over $76 \%$ and $98 \%$ NAR 10 and 30 days since process startup, respectively (Start-up 1).

-In performed experiments, elevated FNA concentrations (Start-up 2) induced more effective NOB inhibition than elevated FA concentrations. Nitrate presence in experiment where FNA was favoured as selective factor was lower and less variable than in start-ups based on FA inhibition. No differences in AOB activity were noticed between process conducted under FA or FNA inhibition.

-Suitable for Anammox process influent composition was obtained in PN reactor (average $\mathrm{NO}_{2}-\mathrm{N} / \mathrm{NH}_{4}-\mathrm{N}$ ratio was $1.24 \pm 0.07$ ) by adjusting borderline $\mathrm{pH}$ set point, thus controlling the alkalinity added with base solution used for $\mathrm{pH}$ control. 


\section{References}

1. M.C. van Loosdrecht, D. Brdjanovic, Science 344, 1452-1453 (2014)

2. C. Hellinga, A.A.J.C. Schellen, J.W. Mulder, M.C. van Loosdrecht, J.J. Heijnen, Water Sci. Technol. 37, 135-142 (1998)

3. J. Guangming, O. Gutierrez, Z. Yuan, Water Res. 45, 3735-3743 (2011)

4. M. Herrero, D. C. Stuckey, Chemosphere 140, 119-128 (2015)

5. M. Strous, J. Heijnen, J. Kuenen, M. Jetten, Microbiol. Biot. 50, 589-596 (1998)

6. S. Lackner, E.M. Gilbert, S.E. Vlaeminck, A. Joss, H. Horn, M.C. Van Loosdrecht, Water Res. 55, 292-303 (2014)

7. G. Tchobanoglous, Wastewater Engineering: Treatment Reuse (Metcalf \& Eddy, Inc. 2003)

8. M. von der Wiesche, A. Wetzel, Water Res. 32, 1653-1661 (1998)

9. Z. Tonkovic, 19th Biennial International Conference, Water Quality International, 165-172 (1998)

10. M.S.M. Jetten, S. Logemann, G. Muyzer, L.A. Robertson, S. de Vries, M.C. van Loosrecht, J.G. Kuenen, A Van Leeuw, J. Microb. 71, 75-93 (1997)

11. I. Jubany, J. Lafuente, J.A. Baeza, J. Carrera, Water Res. 43, 2761-2772 (2009)

12. S. Philips, S. Wyffels, R. Sprengers, Appl. Microbiol. Biot. 59, 557-566 (2002)

13. U. Wiesmann, Adv. Biochem. Eng. Biot. 51, 113-154 (1994)

14. E.V. Munch, P. Lant, J. Keller, Water Res. 30, 2, 277-284 (1996)

15. Y. Ma, Y. Penga S. Wanga, Z. Yuanb, X. Wang, Water Res. 43, 563-572 (2009)

16. J. Claros, E. Jiménez, D. Aguado, Water Sci. Technol. 67, 2587-2594 (2013)

17. S. Park, W. Bae, J. Chung, S.C. Baek, Process Biochem. 42, 1671-1676 (2007)

18. A.C. Anthonisen, R.C. Loehr, J. Water Pollut. Con. F. 48, 835-852 (1976)

19. S. Suthersan, Water Pollution Research Journal of Canada 21, 257-266 (1986)

20. Y. Jeanningros, S.E. Vlaeminck, Water Sci. Technol. 61, 1393-1400 (2010)

21. H. Li, S. Zhou, G. Huang, B. Xu, Process Saf. Environ. 92, 199-205 (2014)

22. G. Ciudad, R. Gonzalez, C. Bornhardt, C. Antileo, Water Res. 41, 4621-4629 (2007)

23. D.J. Kim, D.W. Seo, S.H. Lee, Bioprocess Biosyst. Eng. 35, 441-448 (2012)

24. M.C. van Loosdrecht, P.H. Nielsen, C.M. Lopez-Vazquez, D. Brdjanovic, Experimental Methods in Wastewater Treatment (IWA Publishing, 2016) 